\title{
Premi Asuransi Dana Pensiun Dengan Asumsi Seragam Untuk Kasus Multiple Decrement Menggunakan Metode Aggregate Cost
}

\author{
Aprijon \\ ${ }^{1}$ Jurusan Matematika, Fakultas Sains dan Teknologi, UIN Sultan Syarif Kasim Riau \\ Jl. HR. Soebrantas No. 155 Simpang Baru, Panam, Pekanbaru, 28293 \\ Email: aprijon@uin-suska.ac.id
}

\begin{abstract}
ABSTRAK
Hakikat manusia dalam memenuhi kebutuhan hidup, akan ada banyak sekali kemungkinan-kemungkinan untuk menghadapi kerugian yang disebut dengan resiko.Resiko tersebut juga dirasakan oleh karyawan-karyawan yang bekerja di suatu perusahaan atau lembaga tertentu, terlebih ketika mereka sudah memasuki usia tua. Oleh karena itu,perlu adanya program yang dapat dimanfaatkan untuk jaminan kesejahteraan karyawan dihari tua, salah satunya adalah asuransi dana pensiun. Namun ada kalanya peserta keluar dari asuransi dana pensiun sebelum memasuki masa pensiun normal yang disebabkan oleh faktor lain, misalnya peserta meninggal dunia, cacat permanen dan pensiun awal (multiple decrement). Hal tersebut mengakibatkan pembayaran premi yang harus dibayarkan peserta berbeda dengan pembayaran premi pada saat pensiun normal.Salah satu metode yang digunakan untuk menentukan besarnya premi pensiun yaitu metode aggregate cost. Metode aggregate cost merupakan metode perhitungan premi yang dipengaruhi oleh besarnya gaji serta tingkat kenaikan gaji peserta asuransi selama bekerja. Berdasarkan hasil penelitian, diketahui untuk peserta laki-laki dan perempuan dengan besar gaji, tingkat kenaikan gaji dan usia masuk yang sama, diperoleh bahwa premi yang harus dibayar oleh peserta laki-laki lebih besar daripada premi yang harus dibayarkan oleh peserta perempuan. Hal ini dipengaruhi anuitas awal seumur hidup untuk peserta laki-laki lebih kecil daripada peserta perempuan.
\end{abstract}

Katakunci: asumsi seragam, metode aggregate cost, multiple decrement, premi pensiun.

\begin{abstract}
Human nature to make ends meet, there will be a lot of possibilities to deal with the risk of loss is called.The risk was also felt by employees who work in a particular company or institution, especially when they've reached old age. Hence the need for a program that can be utilized for the welfare of employees on the day old, one of which is the pension insurance fund.But there are times when the participants out of the pension insurance funds before the normal pension caused by other factors, such as the participant's death, permanent disability and due retirement (multiple decrement).This resulted in the payment of premium to be paid by the participant is different premium payment at the time of normal pension. One method used to determine of pension premiums is aggregate cost method.Aggregate cost method is a method of calculating premiums influenced by the amount of salary and the salary increase rate of insurance participants during the work.Based on this research, known for male participants and female with a salary, the rate of increase of salaries and the age of the same sign, the result for the premium to be paid by male participants is greater than the premium to be paid by women only.It is influenced by due life annuity for male is less than the female participants.
\end{abstract}

Keywords: uniform assumption, aggregate cost method, multiple decrement, pension premiums.

\section{Pendahuluan}

Ketakutan akan ketidaktentuan yang mungkin melahirkan kerugian banyak dirasakan oleh karyawan-karyawan yang bekerja di suatu perusahaan atau lembaga tertentu, terlebih ketika mereka sudah memasuki usia tua. Program yang tepat untuk direalisasikan adalah program dana pensiun atau asuransi dana pensiun[1]. Asuransi dana pensiun adalah asuransi yang memberikan uang pertanggungan kepada peserta saat memasuki usia pensiun, hal ini sesuai dengan perjanjian yang telah disepakati oleh kedua pihak, yaitu antara peserta asuransi dan perusahaan asuransi[10].

Sibuea (2013) mengatakan bahwa dalam asuransi dana pensiun, besarnya premi pensiun dipengaruhi oleh manfaat pasti atau uang yang akan diterima oleh peserta asuransi. Premi pensiun adalah 
kewajiban yang dibayarkan oleh peserta asuransi dana pensiun kepada perusahaan asuransi sesuai peraturan dana pensiun[10]. Menurut Futami (1993) besarnya premi yang dibayar dipengaruhi oleh jenis asuransi dan anuitas. Dalam menentukan besarnya premi pensiun anuitas hidup yang digunakan adalah anuitas seumur hidup[7]. Anuitas seumur hidup dipengaruhi oleh peluang bertahan atau peluang hidup dan faktor diskon. Salah satu bentuk untuk menentukan peluang hidup dan peluang keluar peserta asuransi dana pensiun adalah menggunakan asumsi seragam, dimana asumsi seragam merupakan asumsi yang menyatakan bahwa peluang keluar untuk peserta asuransi disetiap waktu itu sama[4].

Salah satu metode yang digunakan untuk menentukan besarnya premi pensiun yaitu metode aggregate cost [9]. Metode aggregate cost merupakan metode yang perhitungannya berdasarkan pengelompokkan dengan persamaan karakteristik tertentu yaitu menunjukkan tingkat iuran normalnya atau premi yang harus dibayar tergantung pada tingkat pembiayaan kewajiban aktuaria pada waktu tertentu, yang menunjukkan nilai manfaat pensiun berdasarkan jasa yang lalu sampai dengan waktu yang telah ditentukan[7].

Premi pensiun pada asuransi dana pensiun sebelumnya telah diteliti oleh Lusiana Sibuea (2013) dengan judul "Metode Aggregate Cost untuk Perhitungan Premi Asuransi Tahunan pada Asuransi Jiwa Gabungan". Penelitian tersebut metode aggregate cost digunakan hanya untuk menghitung besarnya premi tahunan pada asuransi dana pensiun untuk kasus pensiun normal saja. Namun ada kalanya peserta keluar dari asuransi dana pensiun sebelum memasuki masa pensiun normal yang disebabkan oleh faktor lain, misalnya peserta meninggal dunia, cacat permanen dan pensiun awal. Hal tersebut mengakibatkan pembayaran premi yang harus dibayarkan peserta asuransi dana pensiun berbeda dengan pembayaran premi pensiun normal[10,11].

\section{Metode Penelitian}

Pengurangan jumlah nasabah sering sekali terjadi didalam asuransi, termasuk juga dalam asuransi dana pensiun. Pengurangan jumlah peserta asuransi dana pensiun akan berpengaruh kepada besarpeluang bertahan dan peluang keluar dari peserta.Pengurangan nasabah asuransi yang diakibatkan oleh satu kasus disebut single decrement, sedangkan penyebab pengurangan yang lebih dari satu kasus disebut multiple decrement [2].

Misalkan $x$ adalah usia peserta masuk asuransi dan waktu pengurangan merupakan yang dinotasikan dengan $T(x)=T$ yaitu waktu dimana $x$ keluar dari asuransi. Selanjutnya diasumsikan bahwa terdapat $m$ kasus penyebab pengurangan nasabah. Diberikan pula $J(x)=j \quad$ yang merupakan kasus-kasus penyebab pengurangan nasabah dimana $j=$ $1,2, \ldots, m$.

Misalkan $f_{T(x), J(x)}(t, j)$ menunjukkan fungsi distribusi peluang gabungan dari $T(x)$ dan $J(x)$. Gabungan dari fungsi distribusi peluang ini dapat digunakan untuk menghitung peluang dari kejadian-kejadian yang digambarkan oleh $T(x)$ dan $J(x)$.Menurut Finan (2011) Peluang keluar untuk kasus multiple decrement didefinisikan dengan[5]:

$$
{ }_{t} q_{x}^{j}=\int_{0}^{t} f_{T(x), J(x)}(s, j) d s
$$

Peluang keluar untuk kasus single decrement dan multiple decrement dipengaruhi oleh pecepatan mortalita. Menurut Bowers dkk. (1997) percepatan mortalita untuk kasus $j$ dinyatakan dengan[3]:

$\mu_{x}^{(j)}(t)=\frac{f_{T(x), J(x)}(t, j)}{{ }_{t} p_{x}^{T}}$

Berdasarkan Persamaan (1) dan Persamaan (2) percepatan mortalita untuk kasus $j$ dapat dituliskan sebagai berikut:

$$
\mu_{x}^{(j)}(t)=\frac{1}{{ }_{t} p_{x}^{T}} \frac{d}{d t}{ }_{t} q_{x}^{j}
$$

dan percepatan mortalita total untuk semua kasus yaitu:

$$
\mu_{x}^{(T)}(t)=\frac{1}{{ }_{t} p_{x}^{T}}
$$

Berdasarkan Persamaan (2) didapat pula:

$f_{T(x), j(x)}(t, j)={ }_{t} p_{x}^{T} \mu_{x}^{(j)}(t)$

Menurut Bowers dkk. (1997) berdasarkan Persamaan (1) dan Persamaan (4) peluang keluar untuk kasus single decrement dapat di tuliskan dengan:

$$
{ }_{t} q_{x}^{1(j)}=\int_{0}^{t}{ }_{t} p_{x}^{1(j)} \mu_{x}^{(j)}(t) d t
$$

Selanjutnya hubungan peluang bertahan total dan peluang bertahan dengan kasus single decrement yang berhubungan dengan percepatan mortalitayaitu:

$$
\begin{gathered}
{ }_{t} p_{x}^{(T)}=\exp \left\{-\int_{0}^{t}\left[\mu_{x}^{(1)}(s)+\mu_{x}^{(2)}(s)+\cdots\right.\right. \\
\left.\left.+\mu_{x}^{(m)}(s)\right] d s\right\}
\end{gathered}
$$




$$
\begin{aligned}
& { }_{t} p_{x}^{(T)}=\prod_{j=1}^{m} \exp \left\{-\int_{0}^{t} \mu_{x}^{(j)}(s) d s\right\} \\
& { }_{t} p_{x}^{(T)}=\prod_{j=1}^{m}{ }_{t} p_{x}^{1(j)}
\end{aligned}
$$

Menurut Bowers dkk. (1997) menyatakan bahwa Peluang keluar untuk kasus multiple decrement adalah sebagai berikut:

$$
{ }_{t} q_{x}^{(j)}=\int_{0}^{t}{ }_{t} p_{x}^{(T)} \mu_{x}^{(j)}(t) d t
$$

Dalam menentukan besarnya premi pensiun anuitas hidup yang digunakan adalah anuitas seumur hidup.Menurut Futami (1993) anuitas awal seumur hidup untuk kasus multiple decrement dinyatakan dengan[7]:

$\ddot{a}_{x}=\sum_{t=0}^{\omega-x-1} v^{t}{ }_{t} p_{x}^{(T)}$

dengan $\omega$ merupakan perkiraan usia maksimum peserta asuransi, $x$ adalah usia peserta asuransi, ${ }_{t} p_{x}^{(T)}$ merupakan peluang hidup total peserta asuransi dana pensiun yang berusia $x$ tahun dan bertahan hidup hingga pada usia $x+t$ tahun, serta faktor diskon yang dinotasikan dengan $v$ sebagai berikut:

$v=\frac{1}{1+i}$

dimana $i$ adalah Tingkat bunga.

Salah satu metode yang digunakan untuk menentukan besarnya premi pensiun untuk kasus multiple decrement adalah metode aggregate cost. Pada metode aggregate cost besar gaji yang diperoleh setiap tahun akan meningkat dengan tingkat kenaikan gaji yang bersifat konstan.

Menurut Futami (1994) besar gaji peserta asuransi dana pensiun saat usia $x$ tahun untuk $t$ tahun selanjutnya adalah sebagai berikut[8]:

$c_{x+t}=c_{x}(1+z)^{t}$

dengan $c_{x}$ merupakan total gaji peserta asuransi dana pensiun saat usia $x$ tahun dan $z$ menyatakan tingkat kenaikan gaji setiap tahunnya yang diberikan perusahaan. Misalkan $r$ merupakan usia pensiun normal dari peserta dana pensiun dan persentase nilai manfaat pensiun yang ditetapkan oleh perusahaan asuransi dinyatakan dengan $k$, maka besar nilai manfaat pensiun untuk asuransi dana pensiun adalah sebagai berikut:
$B_{r}=k(r-x) C_{r-1}$

Setelah mendapatkan nilai manfaat pensiun maka kita dapat menentukan nilai sekarang manfaat pensiun.nilai sekarang manfaat pensiun dapat ditentukan sebagai berikut:

$\tilde{A}_{x}=B_{r} \quad{ }_{r-x} p_{x}^{(T)} v^{r-x} \ddot{a}_{r}$

Misalkan besarnya premi yang harus dibayarkan oleh peserta asuransi dana pensiun di usia $x$ yang disimbolkan dengan $P_{x}$, Maka secara umum rumus premi pensiun untukasuransi dana pensiun dengan menggunakan metode aggregate cost adalah sebagai berikut:

$P_{x}=\frac{\tilde{A}_{x}-F}{\ddot{a}_{r}}$

\section{Hasil dan Pembahasan}

Premi yang dibayarkan oleh peserta yang keluar dari asuransi dana pensiun atau penyebab diberikannya dana pensiun bagi peserta selain pensiun usia normal yaitu yang disebabkan oleh kasus meninggal dunia, cacat permanen dan pensiun awal. Dimana dalam menentukan peluang keluar dan peluang bertahannya dihitung berdasarkan asumsi seragam. Peluang keluar untuk tiga kasus adalah sebagai berikut[6]:

Kasus meninggal dunia $(j=1)$, berdasarkan Persamaan (8) maka persamaan peluang keluar peserta untuk kasus meninggal dunia adalah sebagai berikut:

$$
\begin{aligned}
& q_{x}^{(1)}=\int_{0}^{1}{ }_{t} p_{x}^{(T)} \mu_{x}^{(1)}(t) d t \\
& q_{x}^{(1)}=q_{x}^{1(1)}\left(1-\frac{1}{2} q_{x}^{1(2)}-\frac{1}{2} q_{x}^{1(3)}+\frac{1}{3} q_{x}^{1(2)} q_{x}^{1(3)}\right)
\end{aligned}
$$

Untuk kasus cacat permanen $(j=2)$ dan kasus pensiun $\operatorname{awal}(j=3)$ dilakukan dengan cara yang sama dengan seperti pada kasus $(j=1)$, maka diperoleh sebagai berikut:

$$
\begin{gathered}
q_{x}^{(2)}=q_{x}^{1(2)}\left(1-\frac{1}{2} q_{x}^{1(1)}-\frac{1}{2} q_{x}^{1(3)}+\frac{1}{3} q_{x}^{1(1)} q_{x}^{1(3)}\right)(16) \\
\text { dan } \\
q_{x}^{(3)}=q_{x}^{1(3)}\left(1-\frac{1}{2} q_{x}^{1(1)}-\frac{1}{2} q_{x}^{1(2)}+\frac{1}{3} q_{x}^{1(1)} q_{x}^{1(2)}\right)
\end{gathered}
$$

Setelah mengetahui peluang keluar untuk kasus multiple decrement dengan menggunakan asumsi seragam, maka berdasarkan Persamaan (9) dapat ditentukan persamaan anuitas awal seumur hidup untuk kasus multiple decrement 


$$
\begin{gathered}
\ddot{a}_{r}=\sum_{t=0}^{\omega-r-1}\left[v^{t}-v^{t} t q_{r}^{1(1)}-v^{t} t q_{r}^{1(2)}-v^{t} t q_{r}^{1(3)}\right. \\
+v^{t} t q_{r}^{1(1)} q_{r}^{1(2)}+v^{t} t q_{r}^{1(1)} \\
\left.q_{r}^{1(3)}+v^{t} t q_{r}^{1(2)} q_{r}^{1(3)}-v^{t} t q_{r}^{1(1)} q_{r}^{1(2)} q_{r}^{1(3)}\right]
\end{gathered}
$$

Setelah mengetahui nilai anuitas awal seumur hidup untuk kasus multiple decrement, dengan mensubtitusi Persamaan (6) dan Persamaan (18) ke Persamaan (13) sehingga diperoleh persamaan nilai sekarang manfaat pensiun untuk kasus multiple decrement adalah sebagai berikut:

$$
\begin{gathered}
\tilde{A}_{x}=\left(k(r-x) C_{r-1}\right) \quad{ }_{r-x} p_{x}^{(T)} v^{r-x}\left[\sum _ { t = 0 } ^ { \omega - x - 1 } \left[v^{t}\right.\right. \\
-v^{t} t q_{r}^{1(1)}-v^{t} t q_{r}^{1(2)}-v^{t} t q_{r}^{1(3)} \\
+v^{t} t q_{r}^{1(1)} q_{r}^{1(2)}+v^{t} t q_{r}^{1(1)} q_{r}^{1(3)} \\
\left.+v^{t} t q_{r}^{1(2)} q_{r}^{1(3)}-v^{t} t q_{r}^{1(1)} q_{r}^{1(2)} q_{r}^{1(3)}\right]
\end{gathered}
$$

Setelah mendapatkan persamaan nilai anuitas awal seumur hidup dan persamaan nilai sekarang manfaat pensiun maka berdasarkan Persamaan (14) rumus umum premi asuransi dana pensiun dengan menggunakan metode aggregate cost adalah sebagai berikut:

$$
\begin{aligned}
& P_{x} \\
& =\frac{\left(k(r-x) C_{r-1}\right){ }_{r-x} p_{x}^{(T)} v^{r-x}\left[\begin{array}{c}
\sum_{t=0}^{\omega-x-1}\left[v^{t}-v^{t} t q_{r}^{1(1)}-v^{t}\right. \\
t q_{r}^{1(2)}-v^{t} t q_{r}^{1(3)}+v^{t} t q_{r}^{1(1)} \\
q_{r}^{1(2)}+v^{t} t q_{r}^{1(1)} q_{r}^{1(3)}+v^{t} t \\
\left.q_{r}^{1(2)} q_{r}^{1(3)}+v^{t} t q_{r}^{1(1)} q_{r}^{1(2)} q_{r}^{1(3)}\right]
\end{array}\right]-F}{\left[\begin{array}{c}
\sum_{t=0}^{\omega-x-1}\left[v^{t}-v^{t} t q_{r}^{1(1)}-v^{t}\right. \\
t q_{r}^{1(2)}-v^{t} t q_{r}^{1(3)}+v^{t} t q_{r}^{1(1)} \\
q_{r}^{1(2)}+v^{t} t q_{r}^{1(1)} q_{r}^{1(3)}+v^{t} t \\
\left.q_{r}^{1(2)} q_{r}^{1(3)}+v^{t} t q_{r}^{1(1)} q_{r}^{1(2)} q_{r}^{1(3)}\right]
\end{array}\right]}(20)
\end{aligned}
$$

\section{Contoh:}

Seorang laki-laki dan perempuan yang masuk menjadi karyawan dan karyawati suatu perusahaan dan mengikuti asuransi dana pensiun pada usia 23 tahun. Usia pensiun yang ditetapkan rumah sakit adalah 56 tahun. Gaji pokok yang diterima karyawan dan karyawati tersebut pada bulan pertama kerja adalah samayaitu sebesar $\mathrm{Rp}$ 1.241.250,00 tiap bulannya dengan kenaikan gaji sebesar 5\% pertahun serta nilai manfaat pensiun yang diberikan perusahaan kepada peserta asuransi dana pensiun adalah sebesar 2,5\%. Pada Februari Tahun 2016 peserta laki-laki tersebut mengalami sakit keras sehingga mengakibatkan meninggal dunia, sedangkan peserta perempuan mengalami kecelakaan fatal yang mengakibatkan cacat permanen. Pihak asuransi akan menghitung besarnya premi terakhir yang harus dibayar peserta dan besarnya manfaat sekarang pensiun yang akan yang harus dibayarkan oleh perusahaan asuransi.
Besar gaji tahun pertama karyawan dan karyawati adalah gaji pokok perbulan dikali 12 bulan sehingga di peroleh yaitu sebesar Rp1.241.250,00 × $12=$ Rp14.895.000,00.

Berdasarkan Persamaan (11) maka diperoleh besar gaji setahun kemudian untuk peserta laki-laki dan perempuanadalah

$c_{24}=\operatorname{Rp} 15.639 .750,00$ sampai $_{55}$ 70.973.803,17.

Berdasarkan Persamaan (12) maka besar manfaat pensiun dengan $k=2,5 \%$ dan menggunakan besarnya gaji yang terakhir adalah sebagai berikut:

$$
\begin{aligned}
B_{r} & =k(r-x) C_{r-1} \\
B_{56} & =\operatorname{Rp} 58.553 .387,62
\end{aligned}
$$

Langkah selanjutnya adalah menentukan besar peluang masing-masing kasus keluarnya peserta laki-laki dan perempuan Besar peluang keluar peserta usia $x=23$ tahun,untuk kasus $j=1$ yaitu:

$$
\begin{aligned}
q_{23}^{(1)}= & q_{23}^{1(1)}\left(1-\frac{1}{2} q_{23}^{1(2)}-\frac{1}{2} q_{23}^{1(3)}+\frac{1}{3} q_{23}^{1(2)} q_{23}^{1(3)}\right) \\
=0,00186(1- & \left(\frac{1}{2} \times 0,00030\right) \\
& -\left(\frac{1}{2} \times 0\right)+\left(\frac{1}{3} \times 0,00030\right. \\
& \times 0))
\end{aligned}
$$

$q_{23}^{(1)}=0,00186$

Besar peluang keluar untuk kasus $j=2$ adalah sebesar $q_{23}^{(2)}=0,00030$ dan besar peluang keluar untuk kasus $j=3$ adalah $q_{23}^{(3)}=0$ serta peluang keluar total di usia 23 tahun adalah sebesar $q_{23}^{(T)}=$ $q_{23}^{(1)}+q_{23}^{(1)}+q_{23}^{(3)}=0,00216$.untuk $q_{24}^{(1)}, q_{24}^{(2)}$, dan $q_{24}^{(T)}$ dari usia 24 tahun sampai usia 56 tahun, di peroleh dengan cara yang sama seperti $q_{23}^{(1)}, q_{23}^{(2)}, q_{23}^{(3)}$ dan $q_{23}^{(T)}$ diatas.

Langkah selanjutnya sebelum menghitung besar manfaat sekarang pensiun dan besarnya premi terlebih dahulu dihitung nilai tunai anuitas awal seumur hidup untuk peserta laki-laki dan perempuan.Untuk perhitungan nilai anuitas awal seumur hidup tingkat bunga yang digunakan sebesar $7 \%$. Berdasarkan Persamaan (17) maka besarnya anuitas awal seumur hidup untuk peserta laki-laki adalah sebagai berikut:

$$
\begin{aligned}
& \ddot{a}_{r}(a)=\sum_{t=0}^{100-56-1}\left[v^{t}-v^{t} t q_{r}^{1(1)}-v^{t} t q_{r}^{1(2)}-v^{t} t q_{r}^{1(3)}\right. \\
& +v^{t} t q_{r}^{1(1)} q_{r}^{1(2)}+v^{t} t q_{r}^{1(1)} q_{r}^{1(3)} \\
& +v^{t} t q_{r}^{1(2)} q_{r}^{1(3)}-v^{t} t q_{r}^{1(1)} q_{r}^{1(2)} q_{r}^{1(3)} \\
& \ddot{a}_{56}(a)=10,80870923
\end{aligned}
$$


Sedangkan besarnya anuitas awal seumur hidup untuk peserta perempuan adalah sebagai berikut:

$$
\begin{aligned}
& \ddot{a}_{r}(b) \\
& =\sum_{t=0}^{103-56-1}\left[v^{t}-v^{t} t q_{r}^{1(1)}-v^{t} t q_{r}^{1(2)}\right. \\
& -v^{t} t q_{r}^{1(3)}+v^{t} t q_{r}^{1(1)} q_{r}^{1(2)}+v^{t} t q_{r}^{1(1)} q_{r}^{1(3)} \\
& \left.+v^{t} t q_{r}^{1(2)} q_{r}^{1(3)}-v^{t} t q_{r}^{1(1)} q_{r}^{1(2)} q_{r}^{1(3)}\right] \\
& \ddot{a}_{56}(b)=10,81426900
\end{aligned}
$$

Selanjutnya dihitung besar nilai sekarang manfaat pensiun untuk peserta laki-laki dan perempuan keluar dari asuransi dana pensiun. Berdasarkan Persamaan (19) dengan $v^{r-x}=0,25841901$, dan $(56-36) p_{36}^{(T)}=0,94522$.

Maka besar nilai sekarang manfaat pensiun untuk peserta laki-lakidiperoleh:

$$
\begin{array}{rl}
\tilde{A}_{x}(a)=B_{r} \quad{ }_{(r-x)} p_{x}^{(T)} v^{r-x} & \ddot{a}_{r}(a) \\
=\operatorname{Rp5} 8.553 .387 & 62 \times 0,94522 \\
& \times 0,258419001 \\
& \times 10,80870923 \\
\tilde{A}_{36}(a)= & \operatorname{Rp} 154.591 .036,55
\end{array}
$$

Sedangkan untuk peserta perempuan nilai sekarang manfaat pensiun diperoleh:

$$
\begin{aligned}
\tilde{A}_{x}(b)=B_{r} \quad(r-x) & p_{x}^{(T)} v^{r-x} \ddot{a}_{r}(b) \\
=\operatorname{Rp} 58.553 .387 & , 62 \times 0,94522 \\
& \times 0,258419001 \\
\times & 10,81426900 \\
\tilde{A}_{36}(b)= & \operatorname{Rp} 154.617 .723,54
\end{aligned}
$$

Setelah dihitung nilai sekarang pensiun, maka dapat ditentukan besarnya premi pensiun asuransi dana pensiun yang harus dibayarkan oleh peserta asuransi dana pensiun. Misalkan jumlah dana pensiun yang diberikan perusahaan kepada peserta asuransi dana pensiun disimbolkan dengan $F$ adalahsebesarRp61.925.963. Berdasarkan Persamaan (19) maka diperoleh besar premi untuk peserta laki-laki pada usiax $=36$ tahun adalah sebagai berikut:

$$
\begin{array}{r}
P_{36}(a)=\frac{B_{56} \quad(56-36) p_{36}^{(T)} v^{56-36} \ddot{a}_{56}(a)-F}{\ddot{a}_{56}(a)} \\
=\frac{\operatorname{Rp} 154.591 .036,55-\mathrm{Rp} 61.925 .963}{10,80870923} \\
=\operatorname{Rp} 8.573 .185,90
\end{array}
$$

Sedangkan besar premi untuk peserta perempuan pada usia $x=36$ tahun adalah sebagai berikut:

$$
P_{36}(b)=\frac{B_{56} \quad(56-36) p_{36}^{(T)} v^{56-36} \ddot{a}_{56}(b)-F}{\ddot{a}_{56}(b)}
$$

$$
\begin{gathered}
=\frac{\operatorname{Rp} 154.591 .036,55-\mathrm{Rp} 61.925 .963}{10,81426900} \\
=\operatorname{Rp} 8.571 .246,06
\end{gathered}
$$

Jadi, besar premi yang harus dibayar oleh peserta laki-laki asuransi dana pensiun tersebut yang terakhir menjadi peserta pada usia $x=36$ tahun adalah sebesar Rp8.573.185,55,sedangkan besarnya premi asuransi yang harus dibayarkan oleh peserta perempuan adalah sebesar Rp8.571.246,06 yang dibayarkan peserta pada awalTahun 2016.

\section{Kesimpulan}

Berdasarkan hasil pembahasan yaitu menghitung besar premi yang harus dibayar oleh peserta asuransi dana pensiun untuk kasus multiple decrement menggunakan metode aggregate costdidapat besarnya gaji dan tingkat kenaikan gaji peserta asuransi selama bekerja sangat berpengaruh dalam perhitungan premi pada metode agregare cost, yaitu semakin besar gaji dan tingkat kenaikan gaji maka semakin besar pula premi yang harus dibayarkan peserta asuransi.

Berdasarkan contoh kasus penerapan diperoleh bahwa besarnya premi yang harus dibayar oleh peserta laki-laki dan peserta perempuan tidak sama yaitu untuk peserta laki-laki premi yang harus dibayar lebih besar daripada besarnya premi yang harus dibayarkan oleh peserta perempuan. Hal ini disebabkan karena anuitas awal seumur hidup untuk peserta asuransi dana pensiun untuk laki-laki lebih kecil dari pada anuitas awal seumur hidup untuk peserta perempuan, karena usia maksimum laki-laki lebih kecil daripada usia maksimum perempuan. Perhitungan peluang keluar menggunakan asumsi seragam juga mempengaruhi anuitas sehingga mempengaruhi besarnya premi yang dibayarkan oleh peserta asuransi dana pensiun.

\section{Daftar Pustaka}

[1] Andriani, Y., Des Alwine, Z., \& Munarsih, E. (2009). Perhitungan Dana Pensiun untuk Pensiun Normal Berdasarkan Metode Constant Dollar; Studi Kasus: PT. Taspen Palembang. Jurnal Penelitian Sains, 12(2).

[2] Badrudin, R., dan Algifari. (1997). Matematika Bisnis Bagian Pertama. BPFE-Yogyakarta, Yogyakarta.

[3] Bower, N. L., et al. (1997). Actuarial Mathematics. The Society or Actuaries, United States Of Amerika. 
[4] Dickson, D. C. M., et al. (2009) Actuarial Mathematics for Life Contingent Risks." Cambrige University Pres, Cambrige.

[5] Finan, M. B. (2011). A Reading of the Theory of Life Contingency Models: A Preparation for Exam MLC/3L.Arkansas Tech university, Arkansas.

[6] Frebsidy, Budi. (2011). Matematika Keuangan Edisi 3 Revisi." Penerbit Salemba Empat, Jakarta.

[7] Futami, T. (1993). Matematika Asuransi Jiwa, Bagian I. Terjemahan Gatot Herlianto. Penerbit Incorporated Fondation Oriental Life Insurance Cultural Development Center, Japan.

[8] Futami, T. (1994). Matematika Asuransi Jiwa, Bagian II. Terjemahan Gatot Herlianto. Penerbit Incorporated Fondation Oriental Life Insurance Cultural Development Center, Japan.
[9] Salim, A. (1993). Asuransi dan Manejemen Resiko. PT Raja Grafindo Persada, Jakarta.

[10] Sibuea, L. (2013). Metode Aggregate Costuntuk Perhitungan Premi Tahunan pada Asuransi Jiwa Gabungan. JOM FMIPAUNRI, Pekanbaru.

[11] Stice, J. D., et al. "Akuntansi Keuangan." Terjemahan Ali Akbar. Penerbit Salemba Empat, Jakarta. 